Creaser, F. H. (1955). J. gen. Microbiol. 12, 288-297

\title{
The Induced (Adaptive) Biosynthesis of $\beta$-Galactosidase in Staphylococcus aureus
}

\author{
BY E. H. CREASER \\ Medical Research Council Unit for Chemical Microbiology, Department \\ of Biochemistry, University of Cambridge
}

SUMMARY : Staphylococcus aureus strain Duncan readily synthesized the adaptive (inducible) enzyme $\beta$-galactosidase in washed suspension when supplied with a mixture of amino acids and an inducer. The amount of enzyme produced was a function of the quantity of amino acids supplied and the rate of synthesis was determined by the concentration of inducer in the system. Galactose was a highly active inducer, lactose a relatively feeble one. Production of the enzyme ensued after a lag period which could be shortened by the addition of glucose or sodium lactate and further shortened by supplying a mixture of purines and pyrimidines to the system. Enzyme formation was strongly inhibited by various antibacterial agents.

It is generally accepted that enzymic adaptation in micro-organisms is a consequence of the synthesis of an enzymically active protein under the influence of an inducer which is usually the substrate or a reaction product of the enzyme in question. Monod, Pappenheimer \& Cohn (1952) showed that the adaptive $\beta$-galactosidase of Escherichia coli appears to be inducible exclusively under conditions which allow the synthesis of new protein. Similarly, Halvorson \& Spiegelman $(1952,1953 a, b)$ concluded that the synthesis of maltozymase in Saccharomyces cerevisiae strain $\mathbf{K}$ was from free amino acids. They also showed that enzyme formation was inhibited by a number of amino acid analogues. Gale \& Folkes $(1953 a, b)$ found that an increase in the protein content of cells of Staphylococcus aureus occurred when these were incubated with glucose and a mixture of those amino acids which were essential nutrients for this organism, protein synthesis being stimulated by the addition of a mixture of purines and pyrimidines. Protein synthesis was inhibited by bactericidal concentrations of aureomycin, terramycin and chloramphenicol and by higher concentrations of other antibiotics. The work to be described was undertaken to ascertain whether the conditions necessary for protein synthesis as described by these authors also applied to the synthesis of adaptive enzymes in $S$. aureus. Price (1952) found that $S$. muscae would grow on lactose after a short lag period: in the present work it is shown that the enzyme $\beta$-galactosidase is adaptive in $S$. aureus. A preliminary note by Gale \& Folkes (1954) has described the development of $\beta$-galactosidase activity in broken $S$. aureus preparations where enzyme formation required a source of energy, a complete mixture of amino acids and an inducer. 


\section{METHODS}

Organism and growth medium. The Duncan strain of Staphylococcus aureus used by Gale \& Folkes $(1953 a, b)$ was also used in this work. The growth medium was that of Gale (1951); it contained salts, $0 \cdot 1 \%(\mathrm{w} / \mathrm{v})$ Marmite, $0 \cdot 2 \%$ $(\mathrm{w} / \mathrm{v})$ arginine and $0.1 \%(\mathrm{w} / \mathrm{v})$ glucose and was prepared in batches of 21 . in 51 . flasks. The organisms were harvested after $15 \mathrm{hr}$. static growth at $37^{\circ}$, washed once in distilled water and resuspended in distilled water. The dry weight of suspensions was estimated by means of a Hilger 'Spekker' absorptiometer previously calibrated for this organism.

Growth inhibition tests. The presence or absence of growth was recorded after $15 \mathrm{hr}$. incubation at $37^{\circ}$ of an inoculum of $c .10^{7}$ cells in $5 \mathrm{ml}$. growth medium containing the growth inhibitory agent under test.

Estimation of $\beta$-galactosidase. The method was based on that of Lederberg (1950) using as substrate o-nitrophenyl- $\beta$-D-galactopyranoside (ONPG) synthesized by the method of Seidman \& Link (1950). It was found with some cell suspensions that hydrolysis of ONPG was enhanced by adding cysteine to the test system. The following procedure was therefore adopted. A sample of the culture under test was centrifuged at $3000 \mathrm{~g}$., the cells washed in $3.0 \mathrm{ml}$. 0.2 M-sodium phosphate buffer $(\mathrm{pH} \mathrm{7.5)}$ and resuspended in $3.0 \mathrm{ml}$. of this buffer. Cysteine $(20 \mathrm{mg} . / \mathrm{ml}$; $1.0 \mathrm{ml}$.) was added and, after temperature equilibration in a $37^{\circ}$ water bath, $1.0 \mathrm{ml}$. of a solution of ONPG $(0.033 \mathrm{M})$. The incubation was continued for a further $30 \mathrm{~min}$. and the cells removed on the centrifuge. The concentration of $o$-nitrophenol in the supernatant was estimated by measuring the absorption at $420 \mathrm{~m} \mu$. using a Beckman spectrophotometer. The readings so obtained were converted to 'enzyme units', one unit being defined as the amount of enzyme liberating $1 \mathrm{~m} \mu$ mole $o$-nitro$\mathrm{phenol} / \mathrm{hr}$. Under these conditions a linear relationship was obtained between absorption and enzyme activity over the range 0 to 10,000 units.

Induction of $\beta$-galactosidase activity in washed suspensions of Staphylococcus aureus. The following inducing system was adopted as standard (quantities/ $\mathrm{ml}.): 400 \mu \mathrm{g}$. each of: L-isomer of DL-alanine, L-aspartic acid, L-cysteine, glycine, L-glutamic acid, L-histidine, L-arginine, L-leucine, L-valine, L-tyrosine, L-proline, L-lysine, DL-serine, DL-isoleucine, DL-threonine, DL-methionine, DL-phenylalanine, DL-tryptophane; $1 \mu \mathrm{g}$. each of adenine, guanine, hypoxanthine, thymine, uracil and xanthine; $1 \mathrm{mg}$. of D-glucose; $20 \mathrm{mg}$. of D-galactose; $2.0 \mathrm{mg}$. dry weight washed suspension of $S$. aureus; $0.0086 \mathrm{M}-\mathrm{KH}_{2} \mathrm{PO}_{4}$; $0.026 \mathrm{M}-\mathrm{NaCl} ; 0.0042 \mathrm{M}-\mathrm{MgSO}_{4} .7 \mathrm{H}_{2} \mathrm{O}$; and $0.035 \mathrm{M}-\mathrm{Na}_{2} \mathrm{HPO}_{4}$. The system was maintained at $37^{\circ}$ in a water-bath and a stream of air bubbled through it.

\section{RESULTS}

Some properties of Staphylococcus aureus $\beta$-galactosidase

Effect of growth conditions. Cells grown in the normal medium had a $\beta$-galactosidase activity of 10-20 units $/ \mathrm{mg}$. dry wt. cells. When the glucose in the medium was replaced by $2 \%(\mathrm{w} / \mathrm{v})$ lactose or $2 \%(\mathrm{w} / \mathrm{v})$ galactose the 
activities of the resulting cells were c. 2000 and 4000 units/mg. dry wt. respectively. Similar differences were observed in the ability of the cells to ferment or oxidise galactose or lactose. The activity of cells grown on glucose was of the same order as that of cells grown without added sugar, showing that the lack of enzyme was not due to supression by glucose and that the differences observed were of an adaptive nature. Such adaptive differences

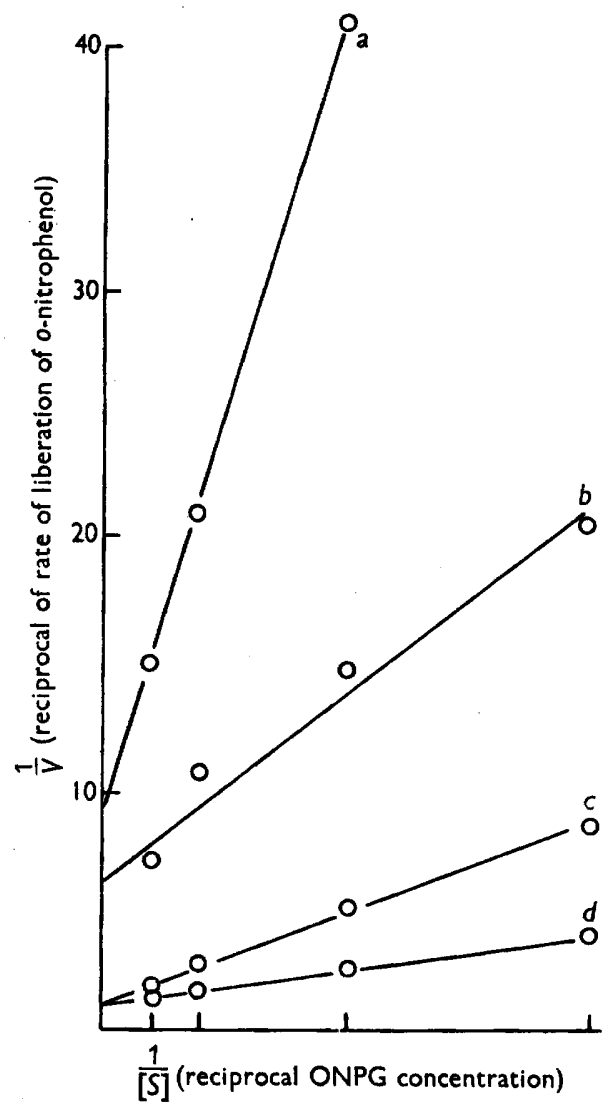

Fig. 1. Effect of lactose, glucose and galactose on ONPG hydrolysis. $1 \cdot 0 \mathrm{mg}$. dry wt. cells suspended in $3.0 \mathrm{ml}$. 0.2 $\mathrm{M}$-sodium phosphate buffer ( $\mathrm{pH} 7 \cdot 5), 1.0 \mathrm{ml}$. cysteine solution $(20 \mathrm{mg} . / \mathrm{ml}$.) and $1.0 \mathrm{ml}$. ONPG solution $(0.033 \mathrm{M})$. Also added; $(a)$ lactose (final concentration $100 \mu \mathrm{g} . / \mathrm{ml}$.); (b) glucose (final concentration $10 \mathrm{mg} . / \mathrm{ml}$.); (c) galactose (final concentration $10 \mathrm{mg} . / \mathrm{ml}$.); $(d)$ no additions. Data plotted according to the method of Lineweaver \& Burke (1934).

were not observed with maltozymase, sucrozymase, melibiozymase, raffinozymase, and enzyme systems which oxidized sodium lactate or sodium acetate. This organism showed no urease, tetrathionase or ability to oxidize sodium benzoate.

Effect of $\mathrm{pH}$. $\beta$-Galactosidase activity of galactose-grown cells was constant over the $\mathrm{pH}$ range $6 \cdot 0-8 \cdot 0$. 
Effect of substrate concentration. The $\beta$-galactosidase in galactose-grown cells had a Michaelis constant of $4 \times 10^{-4} \mathrm{M}$ for ONPG hydrolysis and was competitively inhibited by galactose and non-competitively by lactose and glucose (Fig. 1). The $K_{i}$ for lactose inhibition was $0 \cdot 37 \times 10^{-5} \mathrm{M}$, showing that this Staphylococcus aureus $\beta$-galactosidase has a higher affinity for lactose than for the synthetic $\beta$-galactoside. This is the opposite of the situation found with neurospora lactase (Landman \& Bonner, 1952), Escherichia coli $\beta$-galactosidase (Lederberg, 1950; Cohn \& Monod, 1951) and almond emulsin (Helferich, 1951; Pigman, 1944).

Attempts to obtain a cell-free $\beta$-galactosidase preparation. An active extract was not obtained by treatment with acetone, toluene, butanol or detergents such as cetyltrimethylammonium bromide, Aerosol OT and Tween 80; by lyophilization; by disintegration on the vibrator of Mickle (1948) or in the press of Hughes (1951) or by exposure to ultrasonic vibration; by grinding with alumina (McIlwain, 1948).

\section{Factors affecting $\beta$-galactosidase synthesis in washed suspensions of Staphylococcus aureus}

Cells grown in the glucose-containing medium described above and then incubated in the standard induction system showed a large increase in their ability to hydrolyse ONPG and to oxidize or ferment lactose or galactose. These activities increased together but for most of the experiments only the ability to hydrolyse ONPG was tested. Under the standard conditions the $\beta$-galactosidase activity remained constant at the 'unadapted' level of $c .20$ units/mg. dry wt. over the first hour of incubation (Fig. 2), then increased almost linearly at a maximum rate of $c .2000$ units/mg. dry wt./hr. (Fig. 3) up to a maximum content of $c .4000$ units/mg. dry wt. after about 3-4 hr. incubation (Fig. 7). The activity then decreased; the rate of decline was very variable from one experiment to another (cf. Figs. 6, 7).

Nature and concentration of inducer. Monod, Cohen-Bazire \& Cohn (1951) showed that $\beta$-galactosidase formation in Escherichia coli was induced by lactose, melibiose and galactose, the first two being more efficient than galactose. Galactose is the most efficient inducer in the Staphylococcus aureus system (Fig. 2). Lactose was only about $1 \%$ as active as galactose, whilst melibiose, raffinose, arabinose and galacturonic acid were inactive. The rate of adaptation was proportional to the concentration of galactose present (Fig. 3).

Effect of amino acids. The maximum amount of adaptive enzyme produced was dependent on the concentration of amino acids in the suspension (Fig. 4), the length of the lag phase and the rate of formation being independent of the amino acid concentration. Omission of tryptophan or phenylalanine from the system abolished enzyme formation while omission of cysteine, which was found by Gale \& Folkes (1953a) to be essential for protein synthesis in this organism, decreased the amount of enzyme produced by $62 \%$.

Effect of 4-fluorophenylalanine. When enzyme formation was limited by the amount of phenylalanine in the test system there was a competitive inhibition 
of phenylalanine utilization by 4 -fluorophenylalanine. The effect of the addition of phenylalanine was maximal at a concentration of $25 \mathrm{mg} . / \mathrm{ml}$. When the data were plotted according to the method of Lineweaver \& Burke (1934) the curve obtained consisted of two linear portions (Fig. 5). This type of curve is stated to be due to limitation of the reaction by diffusion of the substrate

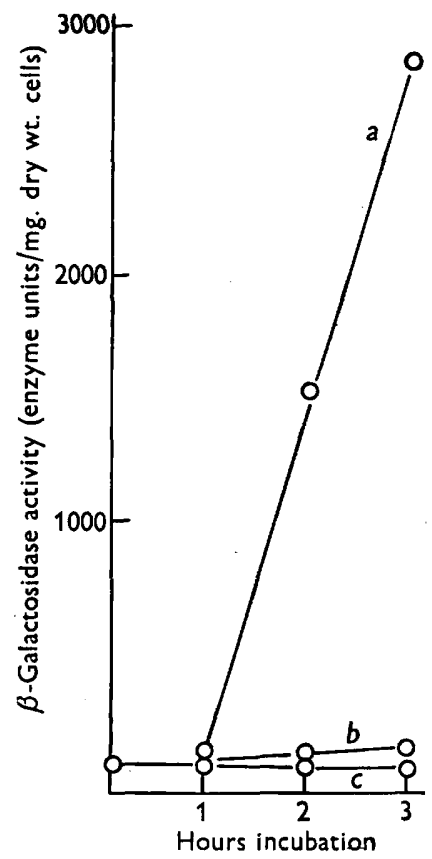

Fig. 2.

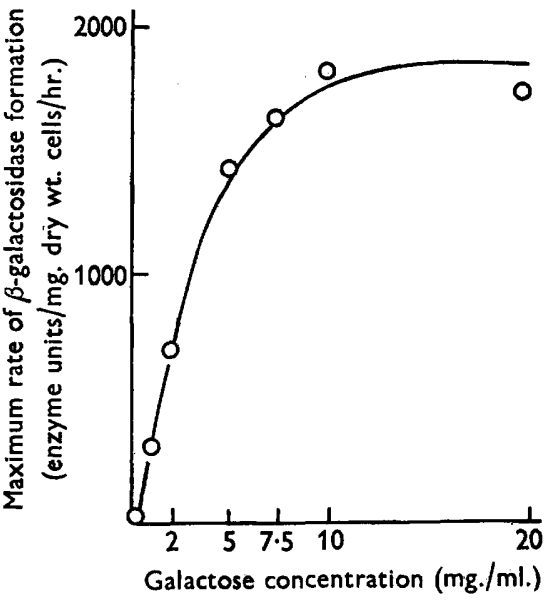

Fig. 3.

Fig. 2. Effect of various inducers on $\beta$-galactosidase formation. Basal system contained amino acids, glucose, salts, purines and pyrimidines. Inducer added to a final concentration of $20 \mathrm{mg} . / \mathrm{ml}$. as follows : $(a)$ galactose, $(b)$ lactose, $(c)$ no inducer, melibiose, raffinose, arabinose or galacturonic acid.

Fig. 3. Effect of galactose concentration of $\beta$-galactosidase formation. Standard conditions with galactose concentration as shown.

(phenylalanine in this case) and is common in reactions which occur in intact cells. No effect of 5-fluorotryptophan in concentrations up to 400 times that of the tryptophan present could be detected.

Effect of glucose, purines and pyrimidines. The synthesis of $\beta$-galactosidase is paralleled by the production of lactozymase and galactozymase. Consequently, when lactose or galactose is used as an inducer enzymic adaptation leads to the utilization of the inducer as a source of energy. In order to diminish the dependence of the induction upon energy supplied by the inducer, a source of energy which would be immediately available without adaptation was added as well as the inducer. Addition of glucose or sodium lactate stimulated the adaptation, principally by decreasing the period of lag; the rate of formation was unaffected but a higher maximum activity was 
produced (Fig. 6). The optimal concentration of glucose was $1 \mathrm{mg} . / \mathrm{ml}$. (higher concentrations were inhibitory); lactate had an optimal effect at $10 \mathrm{mg} . / \mathrm{ml}$. In order to eliminate possible changes in the cells due to the change in carbon source, glucose was used as an energy source for growth and for adaptation

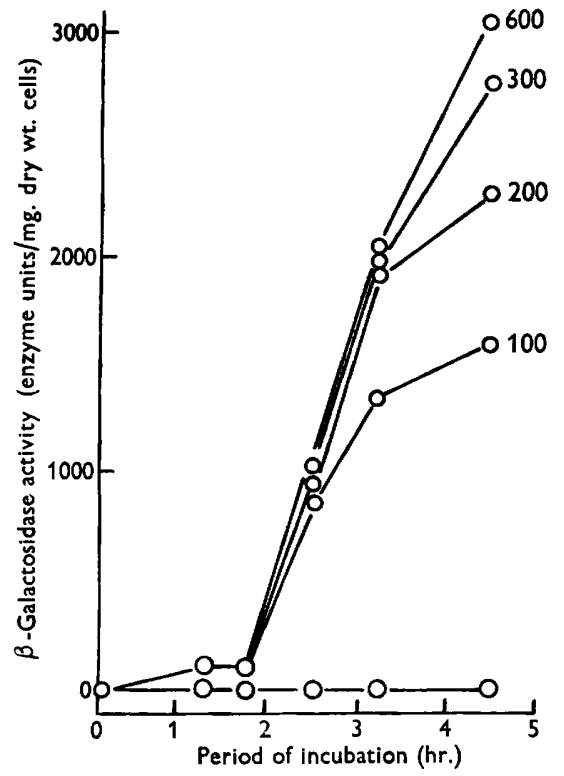

Fig. 4.

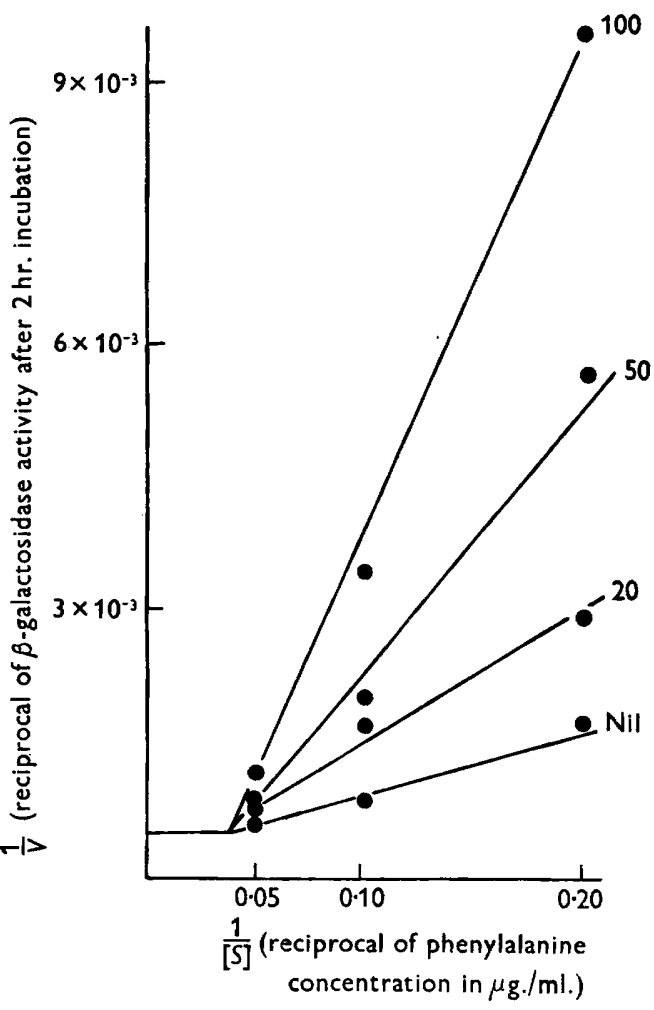

Fig. 5.

Fig. 4. Effect of amino acids on $\beta$-galactosidase formation. Standard conditions with the concentration of amino acids as shown $(\mu \mathrm{g}$. of each amino acid $/ \mathrm{ml}$.).

Fig. 5. Effect of 4-fluorophenylalanine on $\beta$-galactosidase formation. Conditions standard except for the concentration of DL-phenylalanine in the system and the addition of 4-fluorophenylalanine to the final concentration $(\mu \mathrm{g} . / \mathrm{ml}$.) shown. Data plotted according to the method of Lineweaver \& Burke (1934).

procedures. Purines and pyrimidines also diminished the lag period (Fig. 7). In a system containing galactose, amino acids and salts the effect of purines and pyrimidines was about doubled by the presence of glucose; the stimulation of enzyme formation by glucose itself was $20 \%$ greater in the presence of purines and pyrimidines (Table 1).

\section{Inhibition of enzyme formation}

Table 2 shows the effects of various compounds on adaptive enzyme formation. The substances can be divided into three groups: (i) the most active, which completely inhibited adaptation at the same concentration as that 
required to inhibit growth, were neomycin, 2:4-dinitrophenol, puromycin, tetracycline, aureomycin, terramycin and chloramphenicol; (ii) considerable but not completely inhibitory activity at the growth-inhibiting concentration was shown by usnic acid, bacitracin, dihydrostreptomycin and sodium azide;

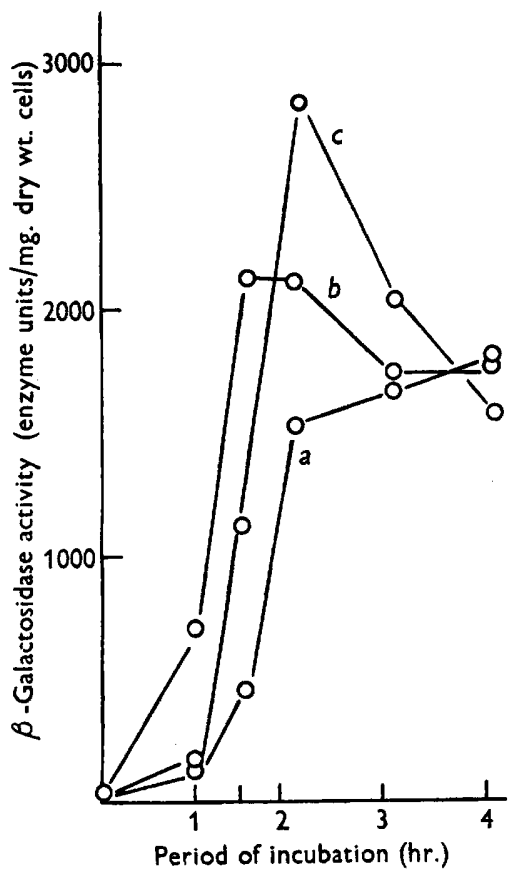

Fig. 6.

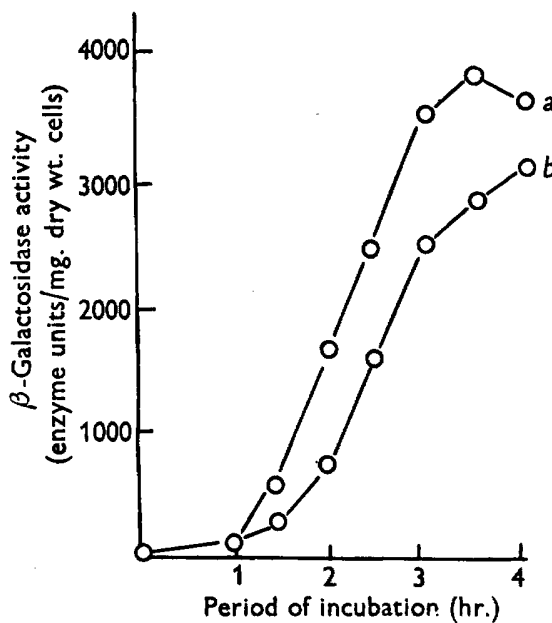

Fig. 7 .

Fig. 6. Effect of energy source on $\beta$-galactosidase formation. Standard conditions except for the energy source which was: $(a)$ nil; $(b)$ sodium lactate $(10 \mathrm{mg} . / \mathrm{ml}$.); $(c)$ glucose (1 mg./ml.).

Fig. 7. Effect of purines and pyrimidines on $\beta$-galactosidase formation. Curve $(a)$ standard conditions; curve $(b)$ purines and pyrimidines omitted.

Table 1. Effect of glucose, purines and pyrimidines on $\beta$-galactosidase formation

Cells were grown in glucose-containing medium and made into a washed suspension before incubation for $2 \mathrm{hr}$. at $37^{\circ}$ in a standard system containing salts, amino acids and galactose. $\beta$-Galactosidase activity was determined after $2 \mathrm{hr}$. incubation and expressed as enzyme units/mg. dry wt. cells.

Further additions to system

(a) Nil

(b) Glucose (1 mg./ml.)

(c) Purines and pyrimidines $(1 \mu \mathrm{g} . / \mathrm{ml}$. of each)

(d) Glucose + purines + pyrimidines concentrations as $(b)$ and $(c)$

\section{$\beta$-galactosidase activity}

368

1184

504

1488
Increased activity due to
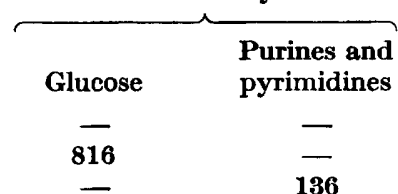

984 
(iii) penicillin and streptomycin were active only at concentrations considerably higher than those required to inhibit growth (penicillin never completely prevented adaptation); actidione and gramicidin did not prevent growth at high concentrations but had some inhibitory effect on $\beta$-galactosidase formation.

\section{Table 2. Inhibition of $\beta$-galactosidase formation}

Washed cells harvested from glucose-containing medium incubated at $37^{\circ}$ in the standard system. $\beta$-Galactosidase activity was determined after $2 \mathrm{hr}$. incubation and expressed as percentage inhibition of formation in the presence of the inhibitor as compared with a control without inhibitor. The growth inhibitory concentration is the minimum concentration of inhibitor which will completely prevent growth in a fully nutrient medium.

\begin{tabular}{|c|c|c|c|}
\hline \multirow[b]{2}{*}{ Compound } & \multirow[b]{2}{*}{$\begin{array}{c}\text { Growth } \\
\text { inhibitory } \\
\text { concentration } \\
(\mu \mathrm{g} . / \mathrm{ml} .)\end{array}$} & \multicolumn{2}{|c|}{$\begin{array}{l}\text { Inhibition of } \beta \text {-galactosidase } \\
\text { formation }\end{array}$} \\
\hline & & $\begin{array}{c}\text { Concentration } \\
\text { of inhibitor } \\
(\mu \mathrm{g} \cdot / \mathrm{ml} .)\end{array}$ & $\begin{array}{c}\text { Inhibition of } \\
\beta \text {-galactosidase } \\
\text { formation } \\
(\%)\end{array}$ \\
\hline Aureomycin & $0 \cdot 03$ & 0.03 & 97 \\
\hline Terramycin & 0.03 & 0.03 & 97 \\
\hline Tetracycline & $0 \cdot 10$ & $0 \cdot 10$ & 93 \\
\hline Chloromycetin & 10 & 10 & 98 \\
\hline Neomycin & $\mathbf{3}$ & $\mathbf{3}$ & 93 \\
\hline Puromycin & 10 & 10 & 100 \\
\hline 2:4-Dinitrophenol & 100 & 100 & 97 \\
\hline \multirow{2}{*}{ Usnic acid } & 30 & 30 & 67 \\
\hline & - & 100 & 100 \\
\hline \multirow[t]{2}{*}{ Bacitracin } & $\mathbf{3 0}$ & 30 & 67 \\
\hline & - & 100 & 100 \\
\hline \multirow[t]{2}{*}{ Dihydrostreptomycin } & 30 & 30 & 56 \\
\hline & - & 100 & 95 \\
\hline \multirow[t]{3}{*}{ Sodium azide } & 100 & 100 & 45 \\
\hline & 一 & 300 & 77 \\
\hline & - & 1000 & 100 \\
\hline \multirow[t]{3}{*}{ Streptomycin } & 30 & 30 & 6 \\
\hline & - & 100 & 70 \\
\hline & - & 300 & 94 \\
\hline \multirow{4}{*}{ Penicillin } & $0 \cdot 01$ & $0 \cdot 01$ & $\mathbf{5}$ \\
\hline & - & $0 \cdot 10$ & $\mathbf{3 0}$ \\
\hline & - & 1.00 & 73 \\
\hline & 一 & 1000 & 73 \\
\hline Actidione & $*$ & 3000 & 72 \\
\hline Gramicidin & * & 3000 & 25 \\
\hline Polymyxin & $3000 \dagger$ & $3000 \dagger$ & 100 \\
\hline
\end{tabular}

\section{DISCUSSION}

The general similarity between the results presented above and those obtained by Gale \& Folkes $(1953 a, b)$ leaves little doubt that enzymic adaptation in Staphylococcus aureus is controlled by the same factors as those which affect protein synthesis. This conclusion is supported by the fact that there is no adaptation in the absence of amino acids and that the effect of amino acids 
can be abolished by the presence of an inhibitory analogue of one of them; it is in line with the conclusions of Monod et al. (1952) and of Halvorson \& Spiegelman $(1953 a, b)$. The fact that glucose and a supply of purines and pyrimidines shorten the lag period indicates that these compounds accelerate some reaction which occurs during this lag and which must take place before formation of adaptive enzyme can begin. It is probable that this reaction is the synthesis of nucleic acid and that this synthesis must occur before adaptive enzyme formation can take place, as suggested by Gale \& Folkes (1954).

The author wishes to express his thanks to the Medical Research Council for a Scholarship for Training in Research Methods, and to Dr E. F. Gale, F.R.S., for much helpful advice and encouragement.

\section{REFERENCES}

Cohn, M. \& Monod, J. (1951). Purification et propriétés de la $\beta$-galactosidase (lactase) d'Escherichia coli. Biochim. biophys. Acta, 7, 153.

Gale, E. F. (1951). The assimilation of amino acids by bacteria. 10. Action of inhibitors on the accumulation of free glutamic acid in Staphylococcus aureus and Streptococcus faecalis. Biochem. J. 48, 286.

Gale, E. F. \& Folkes, J. P. (1953 $a)$. The assimilation of amino acids by bacteria. 14. Nucleic acid and protein synthesis in Staphylococcus aureus. Biochem.J. 53, 483.

Gale, E. F. \& Folkes, J. P. (1953b). The assimilation of amino acids by bacteria. 15. Actions of antibiotics on nucleic acid and protein synthesis in Staphylococcus aureus. Biochem. J. 53, 493.

GALE, E. F. \& Folkes, J. P. (1954). Effect of nucleic acids on protein synthesis and amino acid incorporation in disrupted staphylococcal cells. Nature, Lond. 173, 1223.

Halvorson, H. O. \& Spiegelman, S. (1952). The inhibition of enzyme formation by amino acid analogues. J. Bact. 64, 207.

Halvorson, H. O. \& Spiegelman, S. (1953 $a$ ). The effect of free amino acid pool levels on the induced synthesis of enzymes. J. Bact. 65, 496.

Halvorson, H. O. \& Spiegelman, S. (1953b). Net utilisation of free amino acids during the induced synthesis of maltozymase in yeast. $J$. Bact. 65, 601 .

Helferich, B. In Sumner, J. B. \& Myrback, K., The Enzymes (1951). 1st ed. New York: Academic Press.

Hughes, D. E. (1951). A press for disrupting bacteria and other micro-organisms. Brit. J. exp. Path. 32, 97.

Landman, O. E. \& Bonner, D. M. (1952). Neurospora lactase. 1: Properties of lactase preparations from a lactose utilising and a lactose non-utilising strain. Arch. Biochem. 41, 260.

Lederberg, J. (1950). The beta-D-galactosidase of Escherichia coli, strain K-12. J. Bact. 60, 381.

Lineweaver, H. \& Burk, D. (1934). The determination of enzyme dissociation constants. J. Amer. chem. Soc. 56, 658.

McIlwain, H. (1948). Preparation of cell-free bacterial extracts with powdered alumina. J. gen. Microbiol. 2, 288.

Mickle, H. (1948). A tissue disintegrator. J. R. micr. Soc. 68, 10.

Monod, J., Cohen-Bazire, G. \& Cohn, M. (1951). Sur la biosynthèse de la $\beta$-galactosidase (lactase) chez Escherichia coli. La spécifité de l'induction. Biochim. biophys. Acta, 7, 585. 
Monod, J., Pappenheimer, Jun., A. M. \& Cohn, M. (1952). La cinétique de la biosynthèse de la $\beta$-galactosidase chez $E$. coli considerée comme fonction de la croissance. Biochim. biophys. Acta, 9, 648.

Pigman, W. W. (1944). Specificity, classification and mechanism of action of the glycosidases. Advanc. Enzymol. 4, 41.

PrIce, W. H. (1952). Phage formation in Staphylococcus muscae cultures. XI. The synthesis of ribonucleic acid, desoxyribonucleic acid and protein in uninfected bacteria. J. gen. Physiol. 35, 741.

Seidman, M. \& LiNK, K. P. (1950). $\alpha$-Nitrophenyl- $\beta$-D-galactopyranoside and its tetraacetate. J. Amer. chem. Soc. 72, 4324.

(Received 12 October 1954) 